\title{
PKM SOPIR MIKROLET DI KELURAHAN BATU KOTA MANADO TENTANG
} MANAJEMEN USAHA

\author{
Debby Ch. Rotinsulu ${ }^{1}$, Jacline I. Sumual ${ }^{2}$, Yantje Uhing $^{3}$ \\ ${ }^{1,2,3}$ Ekonomi Pembangunan Fakultas Ekonomi dan Bisnis Unsrat, Manado Indonesia \\ E-mail koresponden : debby_rotin@yahoo.com
}

\begin{abstract}
ABSTRAK
Perkembangan ekonomi suatu daerah tidak terlepas dari pengaruh perkembangan sarana dan prasarana yang mendukung termasuk didalamnya sarana transportasi. Persaingan dunia usaha saat ini membawa para pengusaha jasa transportasi ke persaingan yang sangat ketat dalam rangka memperebutkan konsumen. Berbagai pendekatan dilakukan untuk mendapatkan simpati masyarakat. Semakin banyak jasa transportasi yang beroperasi dengan berbagai produk/jasa yang ditawarkan membuat masyarakat dapat menentukan pilihan sesuai dengan kebutuhan. Kemajuan jasa transportasi saat ini ditandai dengan hadirnya Bisnis Jasa Transportasi Online. Kehadiran jasa Transportasi online ini mempengaruhi keberadaan angkutan Kota antara lain Mikrolet. Pendapatan Sopir Mikrolet yang menurun akibat persaingan dengan angkutan Online disebabkan menurunnya jumlah masyarakat pengguna jasa angkutan kota Mikrolet. Adapun sasaran khalayak dalam pengabdian ini adalah masyarakat yang produktif secara ekonomi yaitu para sopir mikrolet yang ada di Kelurahan Batu Kota. Pengabdian ini berusaha menjawab permasalahan persaingan usaha jasa transportasi. Dengan meningkatkan manajemen usaha jasa transportasi sebagai solusi yang ditawarkan melalui kegiatan PKM nantinya akan meningkatkan pengetahuan, ketrampilan dan motivasi sesuai profesi yang dijalani. Melalui pengabdian ini diharapkan para sopir mikrolet memiliki pengetahuan mengenai cara memanajemen usaha mereka agar bisa menjamin kesinambungan usaha dan tentunya berdampak secara positif terhadap kesejahteraan hidup mereka.
\end{abstract}

Kata kunci : transportasi; mikrolet; online

\section{PENDAHULUAN}

Kemajuan jasa transportasi ditandai dengan hadirnya Bisnis Jasa Transportasi Online. Di berbagai daerah termasuk Kota Manado sekarang ini dipadati dengan kendaraankendaraan baru yang banyak digunakan untuk jas transpotasi online, baik kendaraan bermotor roda 2 atau roda 4. Masuknya jasa Transportasi Online ini menimbulkan berbagai tanggapan yang berbeda di tengah masyarakat. Bagi masyarakat pengguna jasa transportasi umum merasa sangat senang dengan hadirnya taksi online ini. Berbagai kemudahan bisa didapatkan dan ditawarkan. Untuk pengguna taksi Online kendaraan bermotor roda 4 keuntungan yang bisa didapatkan antara lain mudahnya calon penumpang bisa memesan dengan mudah melalui aplokasi pada Hand phone android dengan tujuan tertentu bisa langsung diketahui biaya/ongkos yang akan dikeluarkan. Taksi Online ini akan menjemput calon penumpang langsung di tempat dan mengantarnya sampai ditujuan. Hal ini menguntungkan bagi calon penumpang yang lebih dari 1 penumpang, dan memiliki bawaan barang, jika hujan ataupun panas calon penumpang tetap aman. Begitu juga dengan kendaraan beroda 2/motor memiliki kelebihan lainnya.

Kehadiran jasa Transportasi online ini mempengaruhi keberadaan angkutan Kota Mikrolet. Sejak adanya Taksi online, sangat mempengaruhi pendapatan para sopir mikrolet yakni menjadi turun dibanding sebelumnya. Tidak heran pertama kali kehadiran taksi Online 
ini menimbulkan kontroversi ditengah masyarakat terutama para sopir mikrolet yang melakukan kegiatan Demo/tidak mencari/mogok tidak mengangkut penumpang. Persaingan antara sesama angkutan kota mikrolet sudah dirasakan cukup tinggi karena jumlah mobil mikrolet yang cukup banyak. Kehadiran angkutan Online saat ini dirasakan semakin menambah persaingan mobil angkutan penumpang karena fasilitas yang ditawarkan oleh mobil angkutan Online lebih baik karena kendaraan yang digunakan adalah kendaraan baru dengan memiliki AC begitu uga tak kalah dengan angkutan motor.

Permasalahan Mitra. Berdasarkan analisis situasi di atas, ditemukan bahwa masih banyak Sopir mikrolet yang belum menyadari arti penting manajemen usaha yang mencakup pelayanan terhadap konsumen, cara memposisikan jasa mereka di mata konsumen (misalnya melalui tampilan kendaraan yang menarik), dan cara mengelola keuangan yang tepat, dimana hal-hal tersebut jika diterapkan secara tepat dapat berimbas pada peningkatan kesejahteraan hidup meskipun di tengah nmaraknya persaingan usaha di bisnis transportasi. Menyikapi kondisi di atas, maka sangatlah tepat apabila dalam pengabdian ini diberikan pelatihan tentang manajemen usaha kepada Sopir mikrolet. Penerapan manajemen usaha yang tepat bisa memberikan dampak positif bagi para Sopir mikrolet dalam hal peningkatan kesejahteraan hidup. Berdasarkan hal-hal yang telah dikemukakan sebelumnya, maka dirumuskan masalah sebagai berikut : Bagaimana penerapan manajemen usaha yang tepat bagi Sopir mikrolet di Kelurahan Batu Kota Kecamatan Malalayang mampu membantu meningkatkan kesejahteraan hidup mereka?

\section{KAJIAN LITERATUR}

Angkutan pada dasarnya adalah sarana untuk memindahkan orang dan barang dari suatu tempat ke tempat lainnya. Angkutan umum massal adalah layanan jasa angkutan yang memiliki trayek dan jadwal yang tetap. Dalam hal massal, biaya angkutan umum menjadi beban tanggungan bersama, sehingga system angkutan umum menjadi efisien dalam biaya karena sangat murah (Warpani, 1990). Peranan angkutan umum itu sendiri adalah melayani kepentingan mobilitas masyarakat dalam melakukan kegiatannya. Aspek lain pelayanan angkutan umum adalah peranannya dalam pengendalian lalu lintas, penghematan energi dan pengembangan wilayah. Karena melibatkan banyak orang maka pengguna harus memiliki kesamaan ini pada akhirnya akan menimbulkan berbagai masalah keseimbangan antara ketersediaan dan permintaan. Pelayanan angkutan umum akan berjalan dengan baik apabila dapat tercipta keseimbangan antara sediaan dan permintaan (Warpani, 1990).

Menurut Juara dkk (2016) bahwa jumlah penumpang akan sangat mempengaruhi tinggi rendahnya pendapatan supir angkutan kota, karena dalam sehari tidak dapat dipastikan jumlah pendapatan supir angkutan kota. Jika keadaan lagi ramai maka penumpang yang akan di angkut pun banyak, hal tersebut akan mempengaruhi pendapatan supir begitu juga dengan sebaliknya. Dengan banyaknya transportasi yang semakin muda, maka supir angkutan kota sangat bergantung memperoleh penumpang yang banyak. Jenis angkutan umum dapat dikelompokkan menjadi 6 bagian, yaitu:

1. Angkutan kota Angkutan kota yaitu angkutan dengan kendaraan bermotor umum yang melayani trayek dalam kota yang terdiri dari : Bus besar, bus sedang, dan bus kecil. Angkutan kota yang tidak melayani dalam trayek adalah Taksi.

2. Angkutan perkotaan Angkutan perkotaan yaitu angkutan dengan kendaraan bermotor umum yang pelayanannya melampaui batas kota.

3. Angkutan antar kota Angkutan antar kota yaitu angkutan dengan kendaraan bermotor umum yang melayani trayek antar kota dalam satu provinsi (AKDP) atau antar provinsi dari satu terminal ke terminal lain antar kota antar provinsi (AKAP).

4. Angkutan pariwisata Angkutan pariwisata yaitu angkutan dengan kendaraan bermotor umum yang dipergunakan khusus mengangkut wisatawan ke dan dari suatu daerah tujuan 
wisata.

5. Angkutan sewaan Angkutan sewaan yaitu angkutan dengan kendaraan bermotor umum yang dipergunakan oleh masyarakat dengan cara sewa.

6. Angkutan barang Angkutan barang yaitu angkutan kendaraan bermotor umum yang melayani kegiatan pengangkutan barang.

Biaya Angkutan Umum ditinjau dari sudut pandng masing-masing pihak yang terkait dalam sistem angkutan yaitu pemakai jasa angkutan, perusahaan pengangkutan, pemerintah, daerah, dan pihak-pihak diluar pemakai jasa angkutan. a. Pemakai jasa angkutan memandang ongkos sebagai harga yang dibayar untuk mendapatkan jasa angkutan (misalnya tarif angkutan dan tol), waktu yang dikorbankan untuk kegiatan transportasi, ketidaknikmatan dalam perjalanan, dan kehilangan serta kerusakan dalam pengiriman barang. Konsep ini muncul dari pengertian pengorbanan yang dikeluarkan untuk melakukan perpindahan dengan harapan mendapatkan kepuasan dalam perjalanan. Bila pengorbanan yang dikeluarkan tersebut lebih kecil dari kepuasan yang diterimanya, maka perpindahan akan dilakukan. $b$. Perusahaan pengangkutan memandang ongkos angkutan sebagai ongkos langsung yang dikeluarkan untuk investasi, operasi, dan pemeliharaan fasilitas transportasi. c. Pemerintah memandang ongkos angkutan sebagai pengeluaran yang diperlukan untuk membiayai kegiatan transportasi (misalnya subsidi dan bantuan modal untuk investasi jaringan transportasi). d. Daerah memandang ongkos sebagai pengorbanan tidak langsung karena adanya fasilitas transportasi (misalnya ongkos reorganisasi penggunaan lahan untuk jaringan transportasi. Pihak-pihak di luar pemakai jasa angkutan memandang ongkos sebagai pengorbanan karena perubahan nilai tanah yang digunakan untuk jaringan transportasi dan penurunan kehidupan lingkungan, misalnya kebisingan, polusi dan penurunan nilai-nilai estetika.

\section{METODE PELAKSANAAN}

Adapun metode Pelaksanaan program Kemitraan pada Masyarakat (PKM) bagi para Sopir mikrolet dalam bentuk ceramah dan tanya jawab. Berikut adalah tabel berupa metode yang disampaikan kepada peserta.

Tabel 1. Metode Pelaksanaan

\begin{tabular}{llll}
\hline No. & \multicolumn{1}{c}{ Materi } & \multicolumn{1}{c}{ Alokasi Waktu } & \multicolumn{1}{c}{ Metode Pelatihan } \\
\hline 1. & Customer service & 2 jam & 1.Ceramah \\
& & \multirow{2}{*}{2 jam } & 2. Diskusi/Tanya Jawab \\
2. & Positioning product & 1.Ceramah \\
& & & 2.Diskusi/Tanya Jawab \\
\hline
\end{tabular}

\section{HASIL DAN PEMBAHASAN}

Pelaksanaan Kegiatn PKM Sopir Mikrolet di Kelurahan Batu Kota yang dilaksanakan oleh Tim PKM di sambut dengan baik oleh pihak Pemerintah Kelurahan maupun para sopir walaupun kehadiran sopir mikrolet tidak sebanyak dengan undangan yang telah disebar ke sopir mikrolet mengingat sangat sulit bagi mereka untuk mencari waktu senggang mengikuti kegiatan PKM. Akan tetapi melalui perwakilan beberapa orang sopir mikrolet yang hadir sudah bisa mewakili sopir mikrolet lainnya yang ada di Kelurahan Batu Kota. Kegiatan PKM juga dihadiri oleh beberapa orang Sopir Ojek, dan Sopir Jasa Angkutan Online Gojek yang ingin mengikuti kegiatan ini, juga Tim PKM yang terdiri dari Tim Dosen dan Mahasiswa sebagai pembantu Lapangan.

Pada Tahap pelaksanaan yakni Tim melakukan kegiatan penyuluhan dengan metode ceramah dan Tanya jawab . Pada pelaksanaan kegiatan ini Tim memberikan materi tentang Customer Service yakni bagaimana cara melayani customer dengan baik dan benar yang merupakan bagian dari Service Excellent kepada Cutomer yang harus diperhatikan . Materi 
yang kedua yakni Positioning produk dalam hal ini Mobil Mikrolet yang dimiliki beserta yang ada di dalamnya sehingga menjadi suatu packaging yang menarik. Pada pelaksanaan kegiatan PKM peserta sangat senang dan antusias, pada sesi tanya jawab peserta mengajukan pertanyaan menyangkut bagaimana upaya meningkatkan pendapatan mereka ditengah persaingan dengan angkutan lainnya dalam hal ini transportasi Online.

Manajemen usaha yang baik bagi jasa transportasi patut diterapkan bagi sopir mikrolet untuk meningkatkan pendapatan mereka ditengah persaingan yang ada. Positioning Product dalam hal ini kendaraan yang digunakan yakni Mikrolet tentu saja harus dijaga, dirawat/diperhatikan untuk maintenance nya sehingga tetap terawat, baik sehingga tidak akan kalah bersaing dengan transportasi online. Service yang prima dari sopir kepada customer juga harus diperhatikan, ini merupakan materi-materi yang disampaikan oleh Tim PKM kepada Peserta kegiatan PKM. Untuk mengukur tingkat keberhasilan dari pelaksanaan program, maka dilakukan tahap evaluasi dan monitoring. Setelah dilaksanakan kegiatan penyuluhan oleh Tim, maka selanjutnya tim akan melakukan evaluasi apakah materi yang sudah diterima oleh peserta dapat dipahami betul dengan diterapkannya di lapangan.

\section{KESIMPULAN DAN SARAN}

\subsection{Kesimpulan}

1. Manajemen usaha jasa Transportasi dengan baik dengan konsep Service Excellent bagi Konsumen yakni Penumpang merupakan suatu strategi unutk meningkatkan Pendapatan bagi sopir mikrolet.

2. Quality Product yang terus terjaga dibarengi dengan good Service bagi pelanggan harus diterapkan oleh Sopir mikrolet sehingga bisa bersaing dengan lainnya.

3. Peningkatan Pendapatan Sopir Mikrolet bisa diperoleh ditengah persainagn jasa transportasi lainnya.

\subsection{Saran}

1. Kegiatan PKM diusulkan untuk dilaksanakan bagi sopir jasa transportasi lainnya seperti Gojek, Grab dan Ojek, tidak hanya untuk sopir Mikrolet.

2. Keterlibatan mitra PKM agar lebih banyak dan aktif dan kegiatan PKM.

\section{DAFTAR PUSTAKA}

Boy Syahputra (2014). Analisis Positioning Jasa Transportasi Travel Bandung-Jakarta PP Berdasarkan Persepsi Pelanggan Di Kota Bandung, Jurnal Komunikasi Bisnis Fakultas Komunikasi Dan Bisnis Univ.Telkom

Budi Fermansah (2015). Pengaruh Tarif Dan Kualitas Pelayanan Terhadap Keputusan Penumpang Dalam Memilih Jasa Transportasi PO. Sumber Alam, Jurnal Administrasi Bisnis FISIP UNDIP Semarang

Churnia Ramadhani ( 2016) Analisis Kepuasan Pelanggan Terhadap Layanan Transportasi PO. Eka Mira. Skripsi Jurusan Teknik Industri Fakultas Sains dan Teknologi Universitas Negeri Sunan Kalijaga

Veronica, Supriyono (2016). Pengaruh Kualitas Pelayanan Terhadap Kepuasan Konsumen Jasa Transportasi Kereta Api Indonesia (KAI) Daerah Operasi 6 Yogyakarta, Jurnal Ekonomi STIE Adhi Unggul Bhirawa Surakarta

Nasution, H. M. N, 1996. Manajemen Transportasi, Ghalia, Indonesia Tamin O. Z., 1999.

Tamin O. Z., 1999. P Perencanaan dan Pemodelan Transportasi. ITB. Bandung 